\title{
CHIRONOMID FAUNA OF THE RIVER ANGARA
}

\author{
By Erbaeva E. A. \\ Scientific-Research Institute of Biology at Irkutsk State University, Irkutsk, Russia
}

\section{Introduction}

The Angara is the main river of Eastern Siberia. It flows out of the oligotrophic Lake Baikal and after $1779 \mathrm{~km}$ joins the river Yenissey. The water of the Angara remains baikalian for a significant distance. Even at the mouth of the river $45 \%$ of the total water is baikalian. According to R. A. GolyshKinA (1970) the substratum is composed mainly of stones, due to relief and geological structure. The Angara previously was a mountain river with a high current velocity of $7 \mathrm{~km} \mathrm{~h}-1$ in depositing areas and $12-15 \mathrm{~km} \mathrm{~h}-1$ in eroding areas.

Different authors have studied the chironomid fauna of the Angara. 144 species and forms of Chironomids (Tanypodinae - 10, Diamesinae 10, Prodiamesinae - 2, Orthocladiinae - 63, Chironominae - 59) have been found in it. 5 species (Diamesa baicalensis CHERN., "Orthocladius compactus LINEVICH", $O$. gregarius LINEVICH, O. setosus LINEVICH, Neozavrelia minuta LINEVICH) are endemics of Baikal; Cricotopus angarensis LINEVICH is an endemic of the Angara.

\section{Chironomid fauna before the dams}

A. A. LinEVICH $(1953,1957,1981)$ studied the chironomid fauna over the region from its outflow from Lake Baikal to the city of Bratsk $(670 \mathrm{~km})$ from material collected during the 1940-s. Later, in the middle of 1960-s N. V. VERSHININ (1967) studied the chironomids from the city of Svirsk to Bratsk $(470 \mathrm{~km})$. The chironomid fauna of the lower part of the Angara from the settlement Motygino to its mouth $(123 \mathrm{~km})$ was studied by I. I. GREZE (1953) in the 1950- s.

The Angara from the Lake Baikal outflow to Bratsk is divisible into three parts: 1) from outflow to Irkutsk, 2) from Irkutsk to the inflow of the river Kitoy, 3) from the mouth of Kitoy to Bratsk.

According to A. A. Linevich (1953, 1957, 1981) over the first part representatives of the subfamilies Diamesinae and Orthocladiinae dominated (listed in order of abundance): Diamesa baicalensis CHERN. , "Parorthocladius tridentifer LINEVICH", "Orthocladius compactus LineVICH", O. frigidus (ZETT.), O. trigonolabis ED W., Eukiefferiella coerulescens KIEFF., E. clypeata KIEFF., "E. longicalcar KIEFF. ", E. similis
Goetgh., Diplocladius cultriger KiefF., Pagastia lanceolata (TOK.), Potthastia longimana (KIEFF.), Pseudodiamesa nivosa (Goetgh.), Lauterbornia sp., Polypedilum sp. (Chironomina genuina N3 LIPINA), "Stictochironomus psammophilus CHERN.", i. e. mainly lithorheophillic species.

The second part was dominated by the following species: $D$. baicalensis, $O$. trigonolabis, $O$. frigidus, $O$. compactus, Polypedilum convictum (W ALK.), Pagastia lanceolata, Potthastia gaedii (MEIG.,) Pseudodiamesa nivosa, E. coerulescens, O. consobrinus (HOLMG.), C. angarensis, Eukiefferiella sp., Pagastia orientalis (CHERN.). So, over the second part most species of the genus Eukiefferiella are absent, but lithorheophilic species (subfamilies Diamesinae and Orthocladiinae) continue to dominate.

Over the third part the following species are mentioned: Pagastia lanceolata, Potthastia gaedii, Eukiefferiella coerulescens, $O$. triginolabis, O. compactus, O. frigidus, Polypedilum convictum, Pseudodiamesa nivosa, Monodiamesa bathyphila (KIEFF.), Stictochironomus psammophilus, Polypedilum bicrenatum K IEFF., O. consobrinus, Cryptochironomus gr. defectus (KIEFF.) Harnischia curtilamellata (MALLOCH), Paracladopelma camptolabis (KIEFF.), Paratendipes "connectens" N 3 LIPINA, Tanytarsus exiguus Jo N., Parorthocladius nudipennis (KIEFF.), D. baicalensis and Brillia bifida (KIEFF.) In terms of numbers $P$. lanceolata and $P$. gaedii are first; in terms of the number of species, the subfamily Chironominae dominates.

Unfortunately, I.I. GREZE (1953) does not give a full list of the species of the lower part of the river, but only the dominant ones. The dominant species inhabiting vegetation are the larvae of Tanytarsus exiguus, Polypedilum nubeculosum MEIG., and $O$. thienemanni KIEFF. Vegetation on pebbles is inhabited by T. exiguus, Micropendipes pedellus, Polypedilum scalaenum (SCHRANK) and Glyptotendipes gripenkoveni KIEFF.. Sand is dominated by Chernovskiia orbicus TOWNES (Chernovskia ra ULOMSKY), Robackia demeijerei (KRUS.) and Beckidia zabolotzkyi (GoetGH.), species not found in the upper parts of the river. There are pelorheophilic and psammorheophilic forms dwelling in silted 
sand: the most common among them are Polypedilum bicrenatum KIEFF., P. scalaenum (SCHRANK), Cladotanytarsus gr. mancus (W ALK.), Chironomus gr. thummi (KIEFF.), and Ch. pr. plumosus-reductus LIPINA. Silt is inhabited by Chironomus gr. thummi. General features of the chironomid fauna of the lower part seem to be quite different from those of the upper parts. A rheophilic complex, including baikalian species and mainly composed of species belonging to the Diamesinae and Orthocladiinae, inhabits the typical stony biotopes of the upper parts of the river; this is replaced in the lower parts by a common complex of river forms belonging mainly to the Chironominae. In sandy biotopes the psammorheophils C. ra, R. demeijerei, and Bekidia zabolotzkyi are found.

\section{Present state of the chironomid fauna after erecting the complex of dams}

The river Angara is unaffected initially (about $7 \mathrm{~km}$ ), from Irkutsk to settlement Telma (about $80 \mathrm{~km})$ and below the dam of the Ust-Ilim hydropower station to its mouth $(962 \mathrm{~km})$. Close to its outflow from Lake Baikal the same species that dwelled here before the regulation remain; the 5 baikalian endemic species mentioned above are still to be found. Lithorheophilic forms found in the 40-s dominate. After the regulation in the middle 70 -s we have investigated the river near Angarsk (at $10 \mathrm{~km}$ ). Comparison of the chironomids before and after the regulation has shown some changes in composition (TOMILOV \& al. 1977). O. frigidus, $P$. lanceolata, $P$. gaedi, $O$. consobrinus and $S$. psammophilus which were here before regulation are no longer to be found. $O$. gr. olivaceus and $P$. tridentifer dominate and $D$. baicalensis occurs in stony substrata. In the bottom vegetation $O$. saxicola and $C$. angarensis prevail. Polypedilum sp. (Chironominae sp. N3 LIPINA) and Monodiamesa bathyphila (KIEFF.) dominate in silted sand. During 1973-1975 the chironomid fauna near the future Ust-Ilim reservoir over the $302 \mathrm{~km}$ from Bratsk to Ust-Ilimsk was investigated. 91 species were found, 42 species belonging to the subfamily Chironominae: $D$. baicalensis and $O$. olivaceus dominate in stony sediments; Prodiamesa olivacea and Chironomus obtusidens on small pebbles and silted sand; Cricotopus sylvestris, C. biformis, $O$. frigidus and Diplocladius cultriger on stones covered with algae; Chironomus cingulatus MeIG., Paratendipes albimanus (MEIG.), "Paratrichocladius inaequalis
KIEFF." and Tanytarsus gr. gregarius KIEFF. in silted sediments.

At the end of the 80-s to the beginning of the 90-s we studied the chironomids of the Angara below the dam of the Ust-Ilim power station (KozHOVA \& al. 1993) from the city of UstIlimsk to the mouth of the river Kata (about 90 $\mathrm{km})$. Here there are lot of eroding currents with high velocity: 51 species of Chironomidae were found, about $50 \%$ representatives of the subfamily Orthocladiinae. D. baicalensis, $P$. lanceolata and Pagastia orientalis dominate on stony sediments; Cricotopus sylvestris, $C$. biformis and $O$. saxicola dominate on stones covered with Ulothrix; P. nivosa, P. olivacea, O. olivaceus, Diamesa insignipes KIEFF., Eukiefferiella coerulescens, P. inaequalis and Micropsectra junci (MEIG.) in silted sand and pebbles; Paratendipes albimanus in silt. $O$. frigidus, $O$. consobrinus, $O$. compactus, $O$. gregarius, $C$. angarensis, $P$. inaequalis, $C r$. gr. defectus, Cladopelma viridula (L.), Parachironomus pararostratus, Polypedilum bicrenatum, E. albipennis, Microtendipes pedellus (DE GEER) and Cladotanytarsus gr. mancus (WALK.) found in upper parts are not found here.

\section{Conclusion}

In the river Angara from its outflow from Lake Baikal to its junction with the River Yenissey hydrologic conditions change: decrease of current velocity, increase of water temperature, decrease of transparency, and increase in deposition of sand and silt, i.e. the transformation of a mountain river into the usual Siberian river, and consequent changes in the chironomid fauna take place. In the upper parts of the river lithorheophils of the subfamilies Diamesinae and Orthocladiinae prevail, whereas in the lower part, pelorheophils of the subfamily Chironominae dominate. The main characteristic feature of the river Angara - the influence of Lake Baikal on the fauna (the presence of baikalian endemics) - occurs mainly in the upper part of the river.

\section{References:}

GOLYSHKINA, R.A. 1970. Zoobenthos of the river Angara. Ph. D. Thesis. Irkutsk. 35 pp. (In Russian).

GREZE I. I. 1953. Hydrobiology of the lower parts of the river Angara. Proc. of the Aquatic Ecology Society of the USSR., 5: 203-211. (In Russian) 
Kozhova, O. M., Erbaeva, E. A., Izmest'eva, L.R. \& al. 1993. The distribution of hydrobionts in the river Angara in the region of waste waters of Ust-Ilimsk timber processing plant inflow. VINITI, N 1972B93. 57 pp. (In Russian)

LINEVICH, A.A. 1953. Tendipedids of the upper part of the river Angara. Proc. of Irkutsk State University, 7 (1-2): 153-175. (In Russian)

LiNEVICH ,A.A. 1957. Concerning the larvae of tendipenids of the upper part of the river Angara. Proc. of Biologic-Geographic Scientific-Research Institute, 17 (1-4): 144154. (In Russian)
LiNEVICH, A.A. 1981. Chironomidae of Baikal and Pribaikalye. Novosibirsk, Nauka. 152 pp. (In Russian)

Tomilov, A.A., Erbaeva, E.A., Mekhanikova, I.V. \& al. 1977. Macrozoobenthos of the river Angara near the city of Angarsk. In: Biological investigations of water bodies of Eastern Siberia. Irkutsk, pp. 44-70. (In Russian)

VERSHININ, N.V. 1967. The feeding resources of fishes of the middle Angara river before the regulation (bottom fauna). In: Fishes and feeding resources of basins of rivers and reservoirs of Eastern Siberia. Krasnoyarsk, pp. 261-290. (In Russian) 